Article

\title{
Reconstruction of Lake Level Changes of Groundwater-Fed Lakes in Northeastern Germany Using RapidEye Time Series
}

\author{
Iris Heine $^{1, *}$, Peter Stüve ${ }^{1}$, Birgit Kleinschmit ${ }^{2, \dagger}$ and Sibylle Itzerott ${ }^{1, \dagger}$
}

1 Helmholtz Centre Potsdam, GFZ German Research Centre for Geosciences, Telegrafenberg, Potsdam 14473, Germany; E-Mails: pstueve@arcor.de (P.S.); itzerott@gfz-potsdam.de (S.I.)

2 Geoinformation in Environmental Planning Lab, Technische Universität Berlin, Straße des 17. Juni 145, Berlin 10623, Germany; E-Mail: birgit.kleinschmit@tu-berlin.de

$\dagger$ These authors contributed equally to this work.

* Author to whom correspondence should be addressed; E-Mail: iheine@gfz-potsdam.de; Tel.: +49-331-288-1763; Fax: +49-331-288-1192.

Academic Editor: Y. Jun Xu

Received: 2 April 2015 / Accepted: 23 July 2015 / Published: 31 July 2015

\begin{abstract}
Groundwater-fed lakes in northeastern Germany are characterized by significant lake level changes, but for only a few lakes are in situ water level measurements available. In this study, we test the potential of RapidEye satellite images for indirectly reconstructing lake level changes. The lake levels are derived by intersecting water-land borders with a high-resolution digital elevation model (DEM). Based on Lake Fürstenseer (LF), we define requirements and limitations of the method. Water-land borders were extracted automatically from the 37 RapidEye images available for the period between 2009 and 2014. Otsu's threshold was used for the NIR band and for the normalized difference water index (NDWI). The results were validated with in situ gauging, contour lines from the DEM, and in situ Differential Global Positioning System (DGPS) measurements of the shoreline. Using an ideal shoreline subset, the lake levels could be reconstructed with decimeter accuracy using the NIR water-land border, but the levels were systematically underestimated by $0-20 \mathrm{~cm}$. The accuracy of the reconstructed lake level retrieval strongly depends on the precision of the water-land border retrieval, on the accuracy of the DEM, and on the lake level itself. A clear shift of the water-land border with increasing lake level is also essential for the unambiguous reconstruction of different levels. This shift needs to be several times larger than the pixel size. The biggest challenges
\end{abstract}


for lake level reconstruction are the presence of vegetation at the shorelines, the quality of the topographic data in the underwater area, the slope of the shoreline, and shadows in combination with low solar angles.

Keywords: time series analysis; lake monitoring; lake level measurement; NDWI; NIR; Otsu

\section{Introduction}

The glacial landscape of the northeastern Central European lowlands in Germany and Poland is characterized by a high number of natural lakes. Most are groundwater lakes whose water levels are linked to the local uncovered aquifer. Groundwater and precipitation determine the inflow, evapotranspiration the outflow $[1,2]$. These processes affect the natural dynamic of the lakes and lake level changes. Previous studies showed that groundwater-fed lakes are characterized by small seasonal fluctuations and large perennial changes in lake levels [1,2]. In addition to natural level fluctuations, human interference such as land use and hydromelioration, as well as climate change, influence lake levels $[3,4]$. Lake level changes influence the lakes' physics, chemistry and biology. Lakes in the northeastern Central European lowlands play an important role in ecosystem functions [1]. The most important services of lakes are the protection of biodiversity, water and carbon storage as well as their recreational value (tourism) [4].

In the last few years, field measurements at selected lakes in Germany and Poland showed a significant increase in their lake levels after a long period of continuous sinking [1,5]. A lake level decrease leads to the drying out of the shallow water areas at the shoreline, up to the appearance of sandy sediments. As a reaction, macrophytes, reed, and macrozoobenthos move to deeper water areas. If the change is abrupt the existing flora and fauna vanish [6]. The (temporal) loss of typical underwater and shallow water vegetation is a serious problem because of its contribution to water filtering processes and its function as habitat for fauna [7,8]. Large macrophyte stocks help to stabilize clear water conditions $[1,9,10]$. Their loss can cause a transition from macrophyte-dominated states of lakes with clear water conditions to murky plankton-dominated states [11]. This affects specifically shallow lakes as the smaller lake volume and depth accelerate biological processes and increase eutrophication [12]. Additionally, the loss of vegetation and the drying out of shorelines lead to an increased mineralization of organic matter. If the water level rises and those sediments are flooded again, the mineral substance again dissolves and increases the nutrient content of the water [13].

So far, lake level and shoreline changes have only been monitored at selected lakes. As field monitoring is time consuming and expensive, most lakes in northeastern Germany and Poland are not gauged and their lake level fluctuations could only be estimated. In future, the aim should be to monitor a large number of lakes to build a database for trend analysis. Remote sensing images can be used for lake monitoring and reconstructing past oscillations. Multispectral remote sensing data have been successfully used in the past to monitor and map lakes [14-17] and to monitor coastline changes [18-23]. Lake levels can be measured directly by radar altimetry [24-27] or indirectly by combining topographic data and water-land boundaries [16,28-33]. Indirect reconstruction of lake 
volumes or levels has been accomplished using aerial photos [33] and medium-resolution data [16,28]. It has also been used to reconstruct water surface elevations during inundations using various types of remote sensing data [29-32].

As radar altimeters are profiling tools and their orbital spacing misses too many lakes [31], we use in this study an indirect method to reconstruct lake levels: we test the potential of high-resolution multi-spectral satellite images (RapidEye) for the indirect measurement and reconstruction of small and short-term lake levels changes. The short-term analysis of small lake level changes and high-resolution satellite image data leads to new methodological challenges: in this study, we discuss in detail the influence of shorelines slopes, vegetation and shadows on the accuracy of lake level reconstruction. The large data set for LF, including daily gauging and a shoreline measured in situ, enables absolute validation, whereas previous studies could only compare water-land borders or levels extracted at different times [21,22]. In order to assess the transferability of this lake level reconstruction approach, we examine the attainable accuracy and define requirements and limitations.

\section{Study Area}

Our test site, LF, is a well-researched groundwater-fed lake located near Neustrelitz in Mecklenburg-Vorpommern, Germany (Figure 1). The lake is part of the Mecklenburg Lake District and the geology of its catchment is sandur from the last ice age [34]. The mean annual precipitation at the closest climate station, Carpin-Serrahn [35], is $656 \mathrm{~mm}$ (reference period: 1988-2014). The distribution of the annual precipitation is bimodal with maxima in July (mean: $75 \mathrm{~mm}$ ) and December (mean: $58 \mathrm{~mm}$ ) and minima in April (mean: $35 \mathrm{~mm}$ ) and October (mean: $48 \mathrm{~mm}$ ).

LF is representative of a large number of groundwater-fed lakes in northeastern Central Europe and it has a heterogeneous shoreline, which is essential for analyzing shoreline slope and vegetation.

The lake does not have an active inlet or outlet and is characterized by significant seasonal and inter-annual lake level changes [1,34]. The range of annual lake level oscillation is in the range of $0.2 \mathrm{~m}$ (reference period: 1988-2014) with a local maximum level in April and a local minimum in October in a typical annual cycle. Periods with high lake levels over $83.8 \mathrm{~m}$ a.s.1. (1988/1988, 1995/1996 and 2012/2013) are followed by low water periods with an absolute minimum in 2007 (63.2 m a.s.1.). Consequently, the water surface area of LF varies between 2.1 am $2.6 \mathrm{~km}^{2}$ (GIS analysis based on DEM and in situ level measurements). Between 2009 and 2014, there is a positive trend in lake level due to extraordinarily high precipitation. The gauge data since 1988 and the decomposition of the time series are illustrated in detail in Figure S1.

The average depth of the lake is $8.0 \mathrm{~m}$; the maximum depth is $24.5 \mathrm{~m}$ at a lake level of $63.5 \mathrm{~m}$ a.s.1. (bathymetric survey). The lake is a mesotrophic clear water lake characterized by water stratification [36]. The maximum sight depth, measured via secchi disk between 2004 and 2012, ranges from 4 to $8 \mathrm{~m}$ [37]. In winter, the lake is on average completely covered with ice on 51 days and partly covered on 14 days (reference period: winter 2009/2010-winter 2013/2014) [38]. 


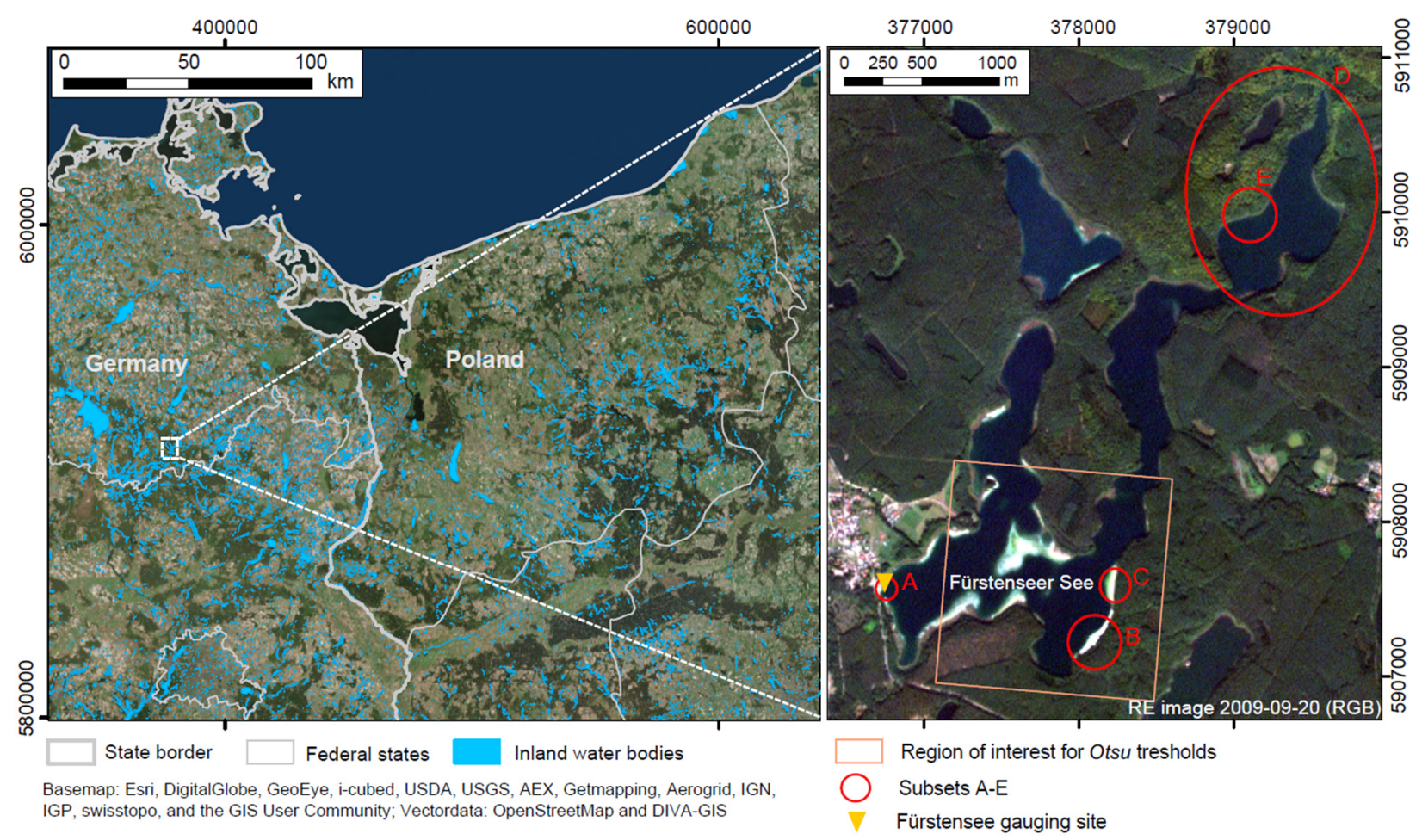

Figure 1. The northern Central European lowlands are characterized by a large number of water bodies. Lake Fürstenseer (LF) is located near Neustrelitz in Mecklenburg-Vorpommern, Germany. The close-up shows a RapidEye satellite image of LF in September 2009 (low lake level). The orange rectangle marks the region of interest for calculating the Otsu thresholds. The red circles mark different subsets of the shorelines (A-E), and the yellow triangle shows the position of the Fürstensee gauging station.

\section{Materials and Methods}

\subsection{Data Acquisition and Preparation}

The LF database includes in situ lake levels, a digital surface model of the terrestrial area adjacent to the lake, bathymetric point data for the lake, and Differential Global Positioning System (DGPS) measurements of the shoreline in August 2014 (Table 1). A workflow of the preparation of the topographic data and the RapidEye images is illustrated in Figure S2.

The Fürstensee gauging site is located at the new public beach (Figure 1, subset A). The processing of the lake level data includes the transfer of the measured relative lake level (in $\mathrm{cm}$ ) to absolute level values in $\mathrm{m}$ above sea level (a.s.1.). The transfer is based on height information provided by the Staatliches Amt für Landwirtschaft und Umwelt Mecklenburgische Seenplatte [38].

Digital surface models with $1 \mathrm{~m}$ resolution, locally only $2 \mathrm{~m}$ resolution, are available nationwide from German government agencies. The digital surface model with $1 \mathrm{~m}$ resolution (ATKIS-DGM1) covering LF is based on two LIDAR acquisitions in winter 2010.

The bathymetric survey took place on 7 October 2002. Despite the time since the survey, the bathymetry is assumed to be still representative because of the closed basin and thus very low levels of erosion and sedimentation at the lake. The survey was conducted by a surveying company on behalf of Landesamt für innere Verwaltung Mecklenburg Vorpommern [39]. In a boat, the surveyors navigated 
in rows over the lake and measured the relative depth $(\mathrm{z})$ from the lake bottom to the water surface. For the transformation to absolute height values, the $\mathrm{z}$ values were subtracted from the in situ gauged lake level in October 2002 (63.53 m). Ca. 46,000 points were measured on the $2.4 \mathrm{~km}^{2}$ lake surface. The distance between rows was $50 \mathrm{~m}$ and the shoreline was not mapped in situ. Based on the in situ measured level, the shoreline was reconstructed as a contour from the ATKIS-DGM1. The shoreline was added to the points of the bathymetric survey as points with zero depth. Then, the underwater surface model was calculated as a Triangulated Irregular Network (TIN). The TIN was resampled to a raster with $1 \mathrm{~m}$ pixel grid size. The accuracy of the underwater surface model is highly dependent on the density of measured points.

Table 1. Overview of the available data.

\begin{tabular}{|c|c|c|c|c|c|}
\hline Data & Abbreviation & Method/Device & $\begin{array}{l}\text { Acquisition } \\
\text { Date }\end{array}$ & $\begin{array}{l}\text { Resolution } \\
\text { (Accuracy) }\end{array}$ & Source \\
\hline $\begin{array}{c}\text { In situ } \\
\text { measured } \\
\text { lake level }\end{array}$ & & $\begin{array}{l}\text { Manual reading at } \\
\text { gauging site }\end{array}$ & $\begin{array}{l}\text { monthly since } \\
\text { 1987, daily } \\
\text { since } 2006 \\
\end{array}$ & $1 \mathrm{~cm}$ & $\begin{array}{c}\text { Staatliches Amt für Landwirtschaft } \\
\text { und Umwelt Mecklenburgische } \\
\text { Seenplatte (MS) [38] }\end{array}$ \\
\hline $\begin{array}{c}\text { Digital } \\
\text { surface } \\
\text { model }\end{array}$ & ATKIS-DGM1 & $\begin{array}{l}\text { Pre-processed } \\
\text { LiDAR }\end{array}$ & $\begin{array}{c}1 \text { November } \\
2010 \text { and } 15 \\
\text { December } 2010 \\
\end{array}$ & $\begin{array}{l}1 \mathrm{~m} \text { (vertical: } \\
0.15-0.2 \mathrm{~m})\end{array}$ & $\begin{array}{l}\text { Landesamt für innere Verwaltung } \\
\text { Mecklenburg-Vorpommern [40] }\end{array}$ \\
\hline $\begin{array}{l}\text { Bathymetric } \\
\text { point data }\end{array}$ & & $\begin{array}{l}\text { Sonar via } \\
\text { SIMRAD-Echolot }\end{array}$ & 7 October 2002 & $\begin{array}{l}\text { (Horizontal: } \\
1 \mathrm{~m} \text {, vertical: } \\
0.1 \mathrm{~m})\end{array}$ & $\begin{array}{c}\text { Ministerium für } \\
\text { Landwirtschaft,Umwelt und } \\
\text { Verbraucherschutz M-V [37] }\end{array}$ \\
\hline $\begin{array}{c}\text { In situ } \\
\text { measured } \\
\text { water-land } \\
\text { border }\end{array}$ & & $\begin{array}{c}\text { Differential Global } \\
\text { Positioning System } \\
\text { via Triumph-VS } \\
\text { Receiver }\end{array}$ & 12 August 2014 & $\begin{array}{c}\text { (Horizontal } \\
\text { RMSE < } 1 \mathrm{~m} \text { ) }\end{array}$ & \\
\hline
\end{tabular}

Finally, an over- and under-water digital elevation model (DEM) of LF was generated by merging the ATKIS-DGM1 and the bathymetric data. Below $63.53 \mathrm{~m}$, the DEM was based on the bathymetric survey and above $63.53 \mathrm{~m}$ on the ATKIS-DGM1 ( $c f$. Figures S4 and 6). The DEM has a $1 \mathrm{~m}$ resolution.

The water-land borders of LF were extracted from RapidEye (RE) satellite images. The data were provided by BlackBridge AG, Berlin, Germany (www.blackbridge.com). RapidEye images were chosen because of their high spatial resolution of $6.5 \mathrm{~m}$, their high temporal resolution, the large size of the archive including data collected since 2009, and the free-of-charge availability for German research projects using the RapidEye Research Archive. Five micro-satellites have provided products since February 2009 with a theoretical temporal resolution of one day (off-nadir) or 5.5 days (at nadir). The sensors on the satellites acquire five spectral bands at wavelengths between 440 and $850 \mathrm{~nm}$, including the red edge band (band 1: 440-510 nm, band 2: 520-590 nm, band 3: 630-685 nm, band 4: 690-730 nm, and band 5: 760-850 nm) [39]. For this study the images were provided in processing level $3 \mathrm{~A}$, delivered as rectangular image tiles. Level $3 \mathrm{~A}$ processing includes orthorectification and resampling to $5 \mathrm{~m} \times 5 \mathrm{~m}$ pixels, as well as radiometric, geometric, and terrain correction of the images [41].

A total of 108 scenes are available showing LF between April 2009 and October 2014. However, 71 scenes were excluded from further analysis due to ice cover, snow or a closed cloud cover above 
the lake. The remaining 37 suitable RapidEye images collected between April 2009 and October 2014 are listed in Table 2. The further preprocessing of the images included the calculation of the top of atmosphere reflectance (TOAR) [41], the co-registration of the stack of images, and cloud masking.

Table 2. Available RapidEye archive data showing LF between April 2009 and October 2014, including the metadata for the acquisitions. The lack of data for 2013 is due to the scarcity of acquisitions because of cloud cover and ice.

\begin{tabular}{|c|c|c|c|c|c|}
\hline $\begin{array}{c}\text { Acquisition } \\
\text { Date } \\
\end{array}$ & Satellite & Sensor & $\begin{array}{c}\text { Sensor Viewing } \\
\text { Angle }\left({ }^{\circ}\right) \\
\end{array}$ & $\begin{array}{c}\text { Sun Elevation } \\
\text { Angle (SEA) }\left(^{\circ}\right) \\
\end{array}$ & $\begin{array}{c}\text { Lake Levels (m a.s.l.) } \\
\text { Measured in situ } \\
\end{array}$ \\
\hline 2009-04-04 & RE-1 & MSI & 0.06 & 42.59 & 63.37 \\
\hline 2009-04-13 & RE-1 & MSI & 13.43 & 45.81 & 63.36 \\
\hline 2009-04-21 & RE-4 & MSI & 6.69 & 48.72 & 63.34 \\
\hline 2009-08-31 & RE-2 & MSI & -3.05 & 45.31 & 63.18 \\
\hline 2009-09-20 & RE-3 & MSI & -2.90 & 37.75 & 63.15 \\
\hline 2010-06-03 & RE-2 & MSI & 17.03 & 59.12 & 63.4 \\
\hline 2010-06-17 & RE-2 & MSI & 20.46 & 60.06 & 63.39 \\
\hline $2010-07-03$ & RE-3 & MSI & 3.68 & 59.74 & 63.34 \\
\hline 2010-07-19 & RE-5 & MSI & 10.38 & 57.56 & 63.29 \\
\hline 2010-09-22 & RE-3 & MSI & 3.53 & 37.05 & 63.32 \\
\hline 2010-10-04 & RE-1 & MSI & 13.16 & 32.40 & 63.31 \\
\hline 2011-04-20 & RE-3 & MSI & -2.94 & 48.26 & 63.54 \\
\hline 2011-05-07 & RE-1 & MSI & 3.49 & 53.54 & 63.51 \\
\hline 2011-05-11 & RE-5 & MSI & -3.18 & 54.59 & 63.5 \\
\hline 2011-05-30 & RE-5 & MSI & -2.95 & 58.50 & 63.52 \\
\hline 2011-06-04 & RE-5 & MSI & -9.79 & 59.11 & 63.51 \\
\hline 2011-06-27 & RE-5 & MSI & 13.60 & 60.10 & 63.53 \\
\hline 2011-09-24 & RE-3 & MSI & 6.88 & 36.34 & 63.7 \\
\hline 2011-10-02 & RE-1 & MSI & -2.96 & 33.05 & 63.7 \\
\hline 2011-10-13 & RE-3 & MSI & 7.07 & 29.00 & 63.7 \\
\hline 2011-10-17 & RE-2 & MSI & 3.91 & 27.42 & 63.7 \\
\hline 2011-10-22 & RE-2 & MSI & -6.11 & 25.52 & 63.7 \\
\hline 2011-11-13 & RE-5 & MSI & -6.21 & 18.63 & 63.68 \\
\hline 2012-04-05 & RE-1 & MSI & -9.61 & 43.05 & 63.92 \\
\hline 2012-05-01 & RE-4 & MSI & 10.25 & 52.08 & 63.94 \\
\hline $2012-05-23$ & RE-2 & MSI & 10.24 & 57.48 & 63.91 \\
\hline 2012-06-18 & RE-4 & MSI & -2.95 & 60.21 & 63.84 \\
\hline $2012-07-24$ & RE-2 & MSI & 7.03 & 56.53 & 63.83 \\
\hline $2012-10-12$ & RE-1 & MSI & 10.00 & 29.07 & 63.77 \\
\hline $2012-11-14$ & RE-5 & MSI & -6.25 & 18.14 & 63.77 \\
\hline 2014-03-10 & RE-5 & MSI & -5.87 & 32.77 & 63.86 \\
\hline 2014-03-20 & RE-1 & MSI & 6.69 & 36.70 & 63.86 \\
\hline 2014-04-25 & RE-3 & MSI & -13.11 & 49.95 & 63.87 \\
\hline 2014-05-01 & RE-5 & MSI & 0.31 & 51.93 & 63.86 \\
\hline 2014-05-20 & RE-5 & MSI & 0.34 & 56.82 & 63.84 \\
\hline 2014-08-06 & RE-2 & MSI & 3.54 & 53.44 & 63.76 \\
\hline 2014-09-05 & RE-3 & MSI & -9.77 & 43.52 & 63.72 \\
\hline
\end{tabular}


To analyze changing water-land borders, precise locating of the RapidEye images is required. We chose a well-positioned master RapidEye image based on a comparison with digital orthophotos. All RapidEye slave images were co-registered to this master image using the script of Behling et al. [42]. Co-registration was based on 100 points per image tile. The maximum root mean squared error (RMSE) of the co-registered slave images to the master image ranges from 0.04 to $1.46 \mathrm{~m}$ and is on average $0.75 \mathrm{~m}$. Finally, clouds were masked using two thresholds in band 1 (blue) and band 3 (red) improved by an additional buffer area of $50 \mathrm{~m}$.

Finally, we measured in situ the shoreline in August 2014 via DGPS. The DGPS measurement of the water-land border took place on 12 August 2014, close to the RapidEye acquisition on 6 August 2014. Additionally, a description of the vegetation at the shoreline and in the water was acquired. The correction of the GPS signal was performed online by the Landesamt für innere Verwaltung Mecklenburg-Vorpommern via SAPOS-HEPS during the field measurement [43]. However, high vegetation at the northern part of the lake led to gaps in the mobile phone network and to inaccuracies in the online correction of the DGPS signal. We removed all points with a horizontal root mean square error $>1 \mathrm{~m}$ to maintain high accuracy.

\subsection{Method}

The lake's water level was reconstructed by intersecting the water-land border with a digital elevation model (DEM), which results in the absolute height of the lake surface (=the lake level) [16,32,33]. The principle is demonstrated in Figure 2. Figure $2 \mathrm{~b}$ also illustrates the challenges caused by vegetation and steep slopes that reduce the distances between contour lines. In practical application, inaccuracies in the extraction of the water-land borders or in the DEM must also be considered. While in the ideal case the water-land border lies on one contour line, in practice the water-land border cuts through several contour lines. Thus, the intersection of the water-land border and DEM results in a range of height values for each date. After a statistical analysis of the height values, the mode value (=most frequent value) for each date is taken as the according reconstructed lake level.

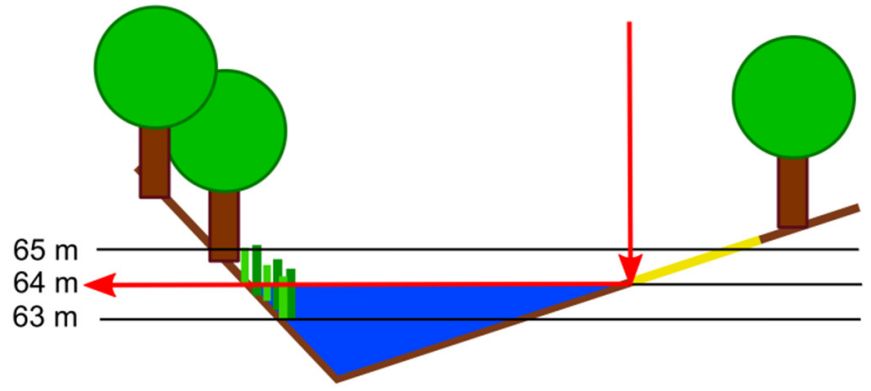

(a)

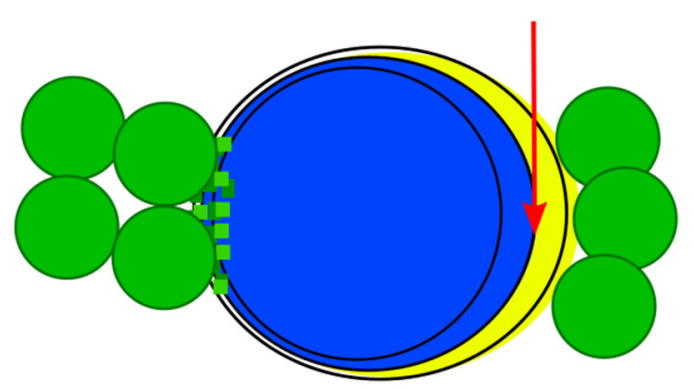

(b)

Figure 2. (a) Scheme of the side view of a lake including its topography; (b) scheme of the top view of a lake including its topography (contour lines). The top view illustrates a satellite image in which the water-land border is delineated. In an ideal case, the water-land border lies on one contour line, in this example at $64 \mathrm{~m}$. This height of the water-land border (=contour line) equals the lake level. 
Two state-of-the-art approaches for distinguishing water-land borders in multispectral images are thresholds in the NIR band $[15,44,45]$ and the use of the Normalized Difference Water Index (NDWI) by McFeeters [46-49]. The formula for calculating NDWI according to McFeeters (1996) [50] is:

$$
N D W I=\frac{\operatorname{Ref}(\text { green })-\operatorname{Ref}(N I R)}{\operatorname{Ref}(\text { green })+\operatorname{Ref}(N I R)}
$$

where Ref is Reflectance.

To delineate the water-land border in the RE images and reconstruct former levels we tested and compared both approaches, the thresholding of the NIR band and the use of NDWI. To avoid subjectivity in the choice of the threshold and to maximize the level of automation, we used the automatic Otsu threshold [49,51]. In a bimodal histogram, the Otsu algorithm calculates the optimum threshold separating the two classes by minimizing the intra-class variance or maximizing the inter-class variance [52]. To calculate the Otsu thresholds, we selected a subset of the southern part of LF and its surroundings (Figure 1). The histograms of NIR and NDWI for this region of interest showed a clear bimodal distribution with the two classes water and land. Based on this threshold, the entire RapidEye image was classified and the shoreline of LF converted to vectors. To reconstruct the lake level, only the longest water-land border of LF was selected and small misclassified polygons were removed.

The extracted water-land borders (NIR and NDWI) from the RapidEye image of 6 August 2014 were validated by the water-land border determined in situ with the DGPS signal. As a degree of precision, we calculated the minimum distances between each DGPS point and the extracted RE water-land borders. Additionally, in the time series we compared all extracted RapidEye water-land borders to the corresponding contour line from the DEM and the in situ gauged lake level. For the evaluation, we separated each RapidEye water-land border into a row of points with $1 \mathrm{~m}$ distance and based on this separation calculated from the DEM the minimum distance to the corresponding contour lines.

The final step was the intersection of the extracted RapidEye water-land border with the high-resolution DEM for the lake level reconstruction. As the shoreline is very heterogeneous with respect to land cover and shoreline topography, we selected and compared different subsets, as recommend by Kaiser et al., 2015 [33]. The subsets were selected based on shoreline slope and vegetation. The slope of the shoreline of LF is defined as the slope (in percent) between 63 and $64 \mathrm{~m}$ a.s.l. The range from 63 to $64 \mathrm{~m}$ a.s.l. represents the rounded range of lake level changes in the last decade. The selected subsets were approximately $40 \mathrm{~m}$ wide to have a minimum size for a statistical analysis of the reconstructed level values.

The entire processing chain of water classification and level reconstruction was implemented using the free software R (version 3.0.1) and is illustrated as a workflow in Figure S2.

\section{Results}

\subsection{Automatic Water-Land Border Extraction}

The comparison of measured DGPS points and the extracted water-land borders (NDWI and NIR) in August 2014 are illustrated in Figure 3a,b. The boxplots in Figure 3a represent the calculated minimum distances between the DGPS points and the extracted water-land borders using NDWI and 
NIR. Negative distances imply that the extracted water-land border is inside the in situ determined boundary (underestimation of the water extent); positive distances imply that the extracted water-land border is outside the in situ determined boundary (overestimation of the water extent).
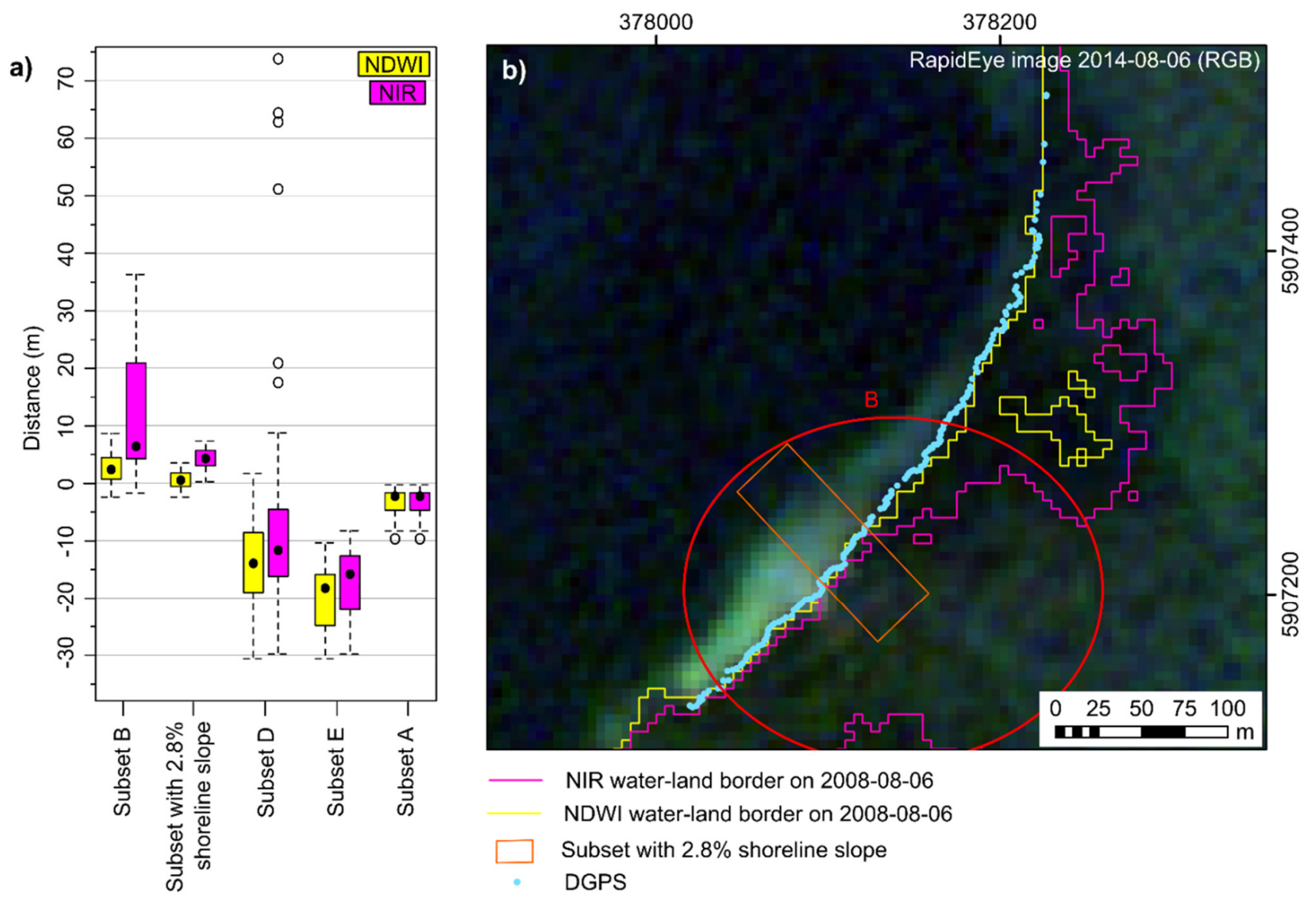

Figure 3. (a) shows the minimum distances between the DGPS points and the extracted water-land borders (NDWI and NIR) at different subsets ( $c f$. Figure 1). Negative distances show an underestimation of the extracted water-land border, meaning that the extracted water-land border is inside the in situ determined boundary. Positive distances show an overestimation, meaning that the extracted water-land border is outside the in situ determined boundary. The black dots represent the median value; (b) illustrates the reconstructed and in situ determined water-land borders at the southeastern part of LF. The reconstructed water-land borders were mapped in the RapidEye image using Otsu's threshold in the NIR (pink line) and the NDWI (yellow line) images. The in situ determined water-land border was measured via DGPS (light blue dots).

Eye-catching in Figure $3 \mathrm{a}$ are the ranges of negative and positive deviations. High deviations for NIR in subsets B and D result from misclassifications caused by the dark cloud shadows in the RapidEye image (6 August 2014). The NIR water-land border spreads massively into the land area with deviations up to $80 \mathrm{~m}$. The NDWI water-land border also shows misclassifications in the land area, but the lake shoreline remains intact. Large negative deviations are caused by dense reed and overhanging trees (subset E). Subset B is not completely free of vegetation as reed grows there sparsely (mapped in summer 2014). There are beech trees growing around the lake. In summer 2014, 
at a level of $63.77 \mathrm{~m}$, the water was close to, but not yet under the trees. Here, the deviations between DGPS and NIR/NDWI water-land borders are caused by inaccuracies in water extraction. The overestimation of the NIR water-land border at subset B is mainly caused by cloud shadow, but also in the smaller subset without direct cloud shadow the NIR water-land border is overestimated on average by $4 \mathrm{~m}$ (range: $0 \mathrm{~m}-7 \mathrm{~m}$ ). The NDWI water-land border at the subset with $2.8 \%$ slope differs on average by $1 \mathrm{~m}$ from the DGPS-derived shoreline. The height differences between the DGPS-derived shoreline and the RapidEye water-land borders range from 0.05 to $0.25 \mathrm{~m}$ (NIR) and 0 to $0.20 \mathrm{~m}$ (NDWI) at the subset with $2.8 \%$ slope.

The new public beach (subset A) is only $50 \mathrm{~m}$ wide, with a very small sandy stripe ( $c a .2 .5 \mathrm{~m}$ in August 2014) and lawns behind. Here, the extracted water-land borders using NDWI and NIR are identical, with an underestimation of $0 \mathrm{~m}-10 \mathrm{~m}$. The height difference between the DGPS shoreline and the NDWI/NIR water-land borders is between 0 and $0.25 \mathrm{~m}$.

Not only cloud shadow, but also shadows behind rows of trees and buildings caused misclassifications using the NIR image. These small misclassified polygons were removed for the reconstruction of the lake level and only the longest line was taken as the water-land border.

\subsection{Shoreline Changes}

In addition to the validation using DGPS measurements, the extracted water-land-borders (NDWI and NIR) were compared to the according contour lines at different lake levels. Figure 4 illustrates the water-land borders and the contour lines at minimum level (63.15 m a.s.1.) on 20 September 2009, two intermediate levels, and the near-maximum level (63.91 m a.s.1.) on 23 May 2012 (cf. Figure S1). The changes of the water-land border at the southeastern beach of LF are illustrated in smaller scale in Figure S3. The lake levels on 1 May 2012 (63.94 m a.s.1., maximum level) and 5 April 2012 (63.92 $\mathrm{m}$ a.s.1.) were slightly higher, but clouds covered large parts of LF.

The contour lines from the DEM (Figure 4c) show clear changes of the shoreline with increasing lake level. In the southwestern very shallow area (slope: $0 \%-3 \%$ ), the contour lines move up to $150 \mathrm{~m}$ between the minimum and maximum extent. The sandbank that is visible in the RapidEye image is, however, not detected. This error is caused by the large gap of bathymetric points in the shallow water area and the resulting significant underestimation of the height in this area (cf. Figure S4).

On the vegetation free southeastern beach, the NIR water-land borders (Figure 4a) clearly show the changes in lake level. The NIR water-land border moves up to $35 \mathrm{~m}$ between the minimum and maximum extent, whereas the NDWI water-land borders (Figure 4b) are clearly overestimated at the low and intermediate lake levels ( $c f$. the close-up in Figure S3). The position of the NDWI water-land border at low water levels (20 September 2009) fits neither the GIS analysis nor photos from 2009 that show a wide sand beach (Figure S5).

The sandbank in the middle of the southern part of LF is detected via NIR and NDWI. In the NIR image it has a size of $c a .3300 \mathrm{~m}^{2}$ at minimum water level (20 September 2009) and shrinks with increasing levels to $c a .300 \mathrm{~m}^{2}$ on 21 April 2009. In the NDWI image it is at $c a .300 \mathrm{~m}^{2}$ also much smaller than in the NIR water-land border and only detected at the minimum level.

Due to the importance of topographic data for lake level reconstruction, Figure 5 illustrates the NIR water-land borders and the according contour lines at low and high levels as well as the topographic 
data. The underwater surface model is based on bathymetric points and the contour line on the day of the bathymetric survey. The gap between the point data and the contour line ranges in the shallow water area from $c a .15 \mathrm{~m}$ to $c a .40 \mathrm{~m}$, depending on the slope of the shoreline. It is unavoidably larger in the shallower subsets.

Whereas the low lake level falls in the area of the underwater surface model, the high level falls in the area covered by ATKIS-DGM1. Thus, these two quality levels of the topography need to be kept in mind for the further analysis. The distance between the contour line and the NIR water-land border at low lake levels is larger than the distance between both at high lake levels ( $c f$. Figure 6). In the subset with $2.7 \%$ slope the high deviation between the extracted NIR water-land border and the contour line sticks out. This deviation is caused by flooded trees. It must also be considered that there is a deviation between the NIR water-land borders and the contour lines because of the different resolutions of the RapidEye image and the DEM.

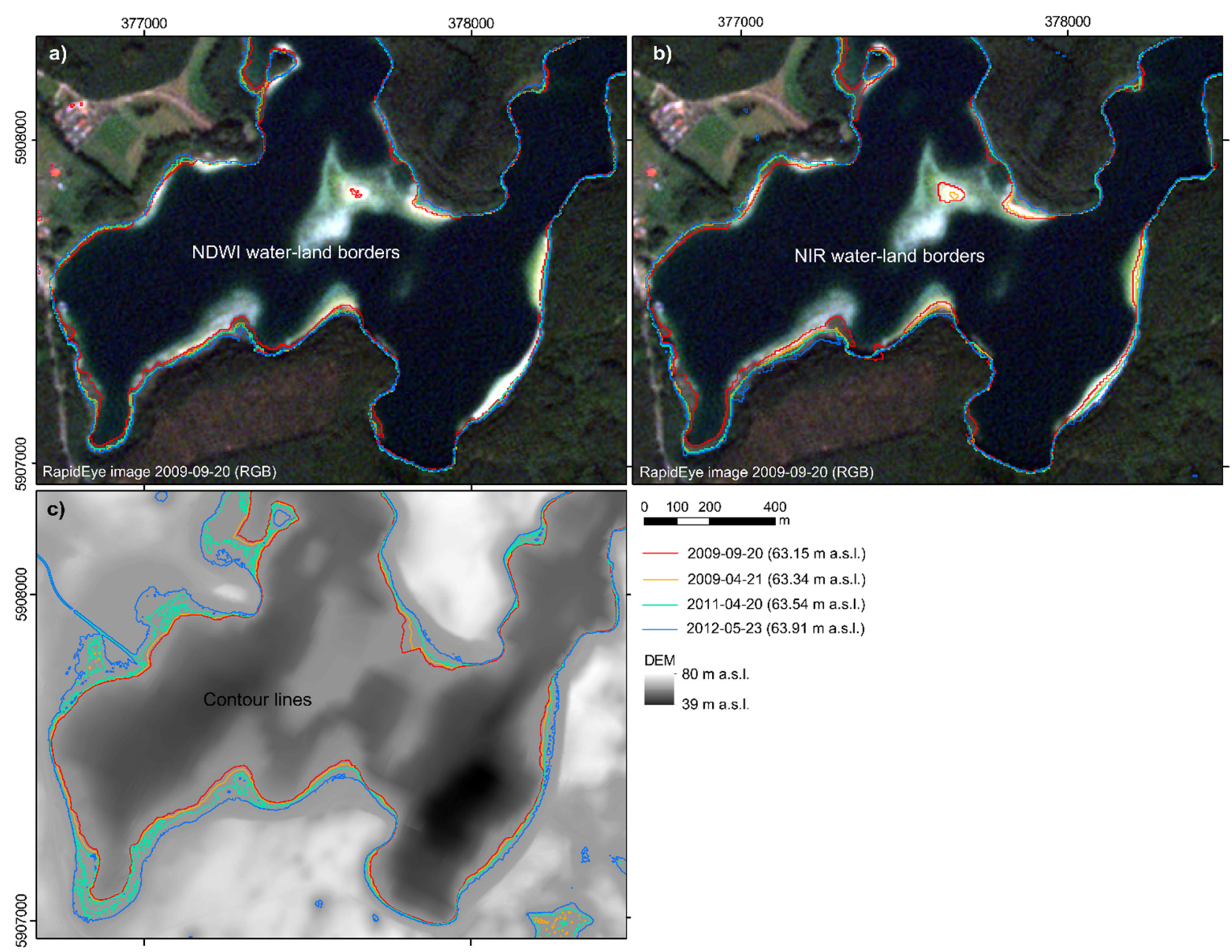

Figure 4. Illustration of the water-land borders on 21 April 2009, 20 September 2009, 20 April 2011, and 23 May 2012. (a) shows the water-land borders extracted from the RapidEye images using the NDWI; (b) shows the water-land borders extracted from the RapidEye images using the NIR; (c) represents the GIS analysis with contour lines: The levels measured in situ on the four dates are delineated as contour lines in the DEM. The minimum level (63.15 m a.s.1.) between 2009 and 2014 was measured on 20 September 2009, the maximum level on a cloud free image (63.91 m a.s.1.) on 23 May 2012. 


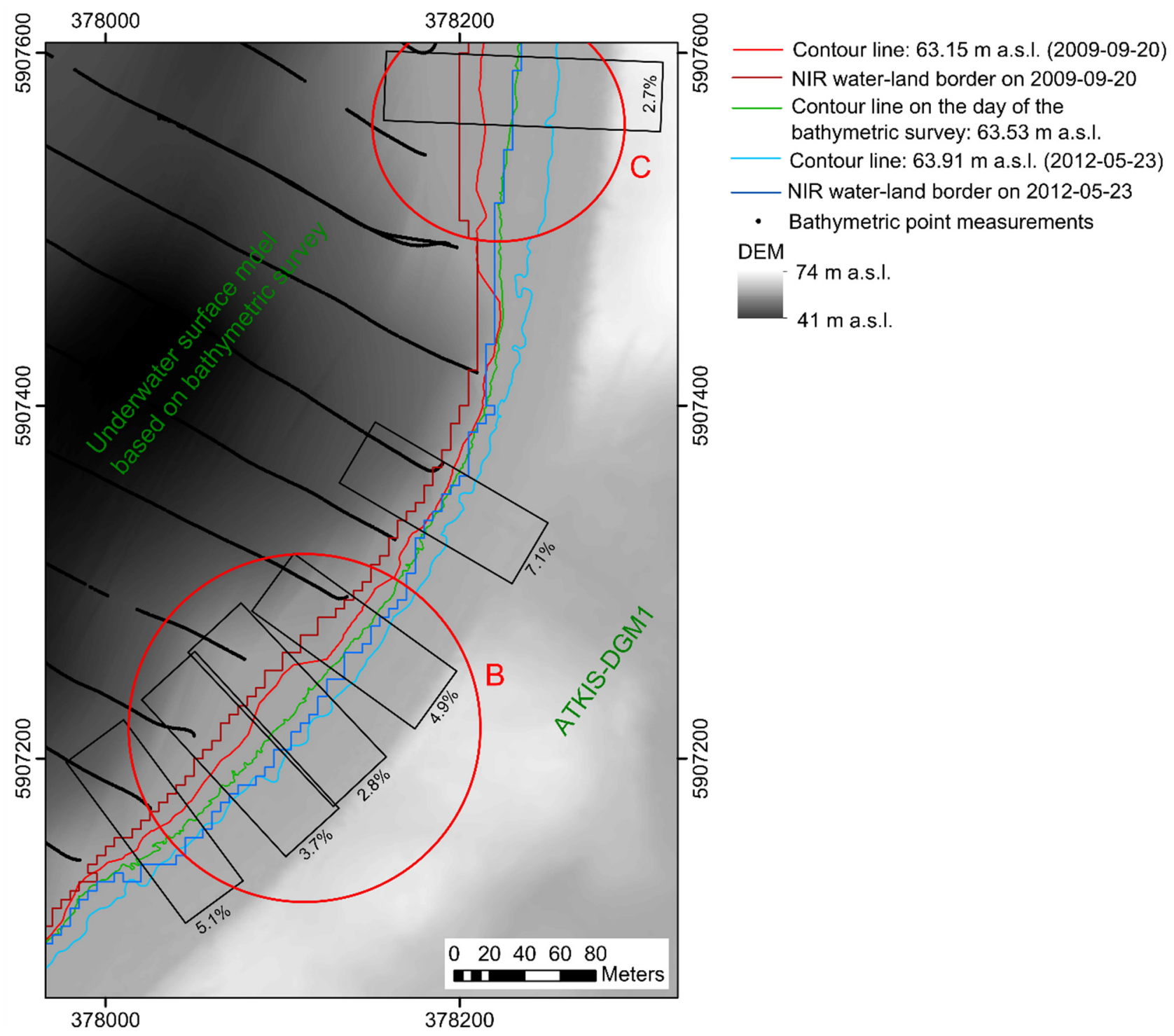

Figure 5. Digital elevation model, NIR water-land borders and corresponding contour lines at the southeastern part of LF (subsets B and C). The red and blue lines illustrate the deviation between the reconstructed water-land borders and the contour lines at the minimum lake level (20 September 2009, $63.15 \mathrm{~m}$ a.s.1.) and its maximum level in a cloud free image (23 May 2012, $63.91 \mathrm{~m}$ a.s.1.). The toothed shorelines (dark red and dark blue) were extracted from the RapidEye NIR image. The smoother lines (bright red and bright blue) are the contour lines from the DEM based on levels measured in situ. The green line illustrates the contour line on the day of the bathymetric survey (63.53 $\mathrm{m}$ a.s.1.). The measured bathymetric points are the black dots. Different subsets and their slopes (in percentage) are noted. 


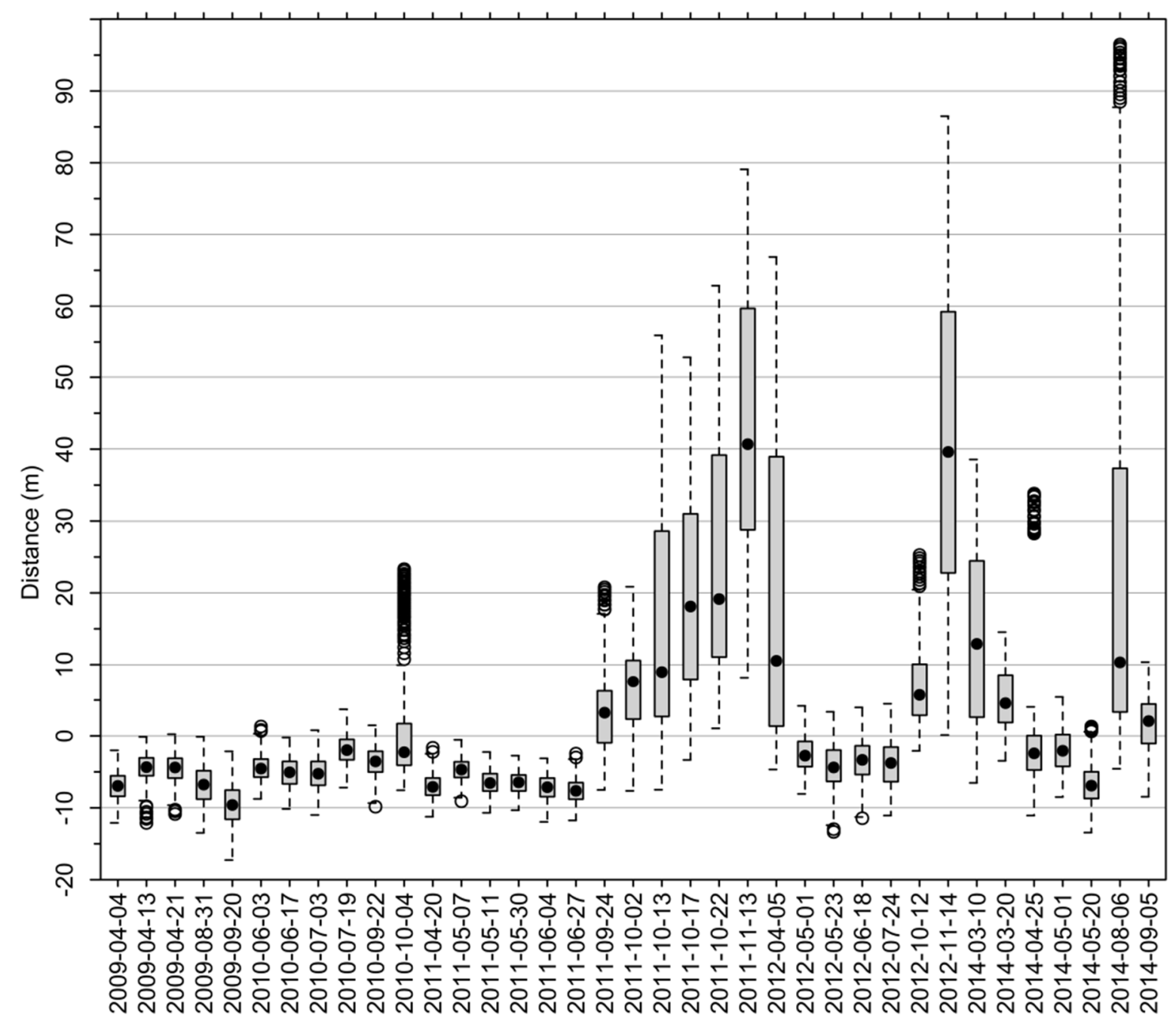

Figure 6. Boxplot of the minimum distances (in $\mathrm{m}$ ) between the RapidEye water-land borders (NIR) and the according DEM contours at subset B. The black dots represent the median. The root mean squared error (RMSE) for all dates is $21.1 \mathrm{~m}$. The RMSE is reduced to $10.8 \mathrm{~m}$ when dates with a very low sun elevation angle (SEA) below $30^{\circ}$ and dates with a SEA angle below $45^{\circ}$ in cases of high lake levels ( $\geq 63.7 \mathrm{~m}$ a.s.1.) are excluded.

A comparison of the contour lines from the DEM with the extracted NIR water-land borders of the entire time series is illustrated in Figure 6. It is based on subset B. On 24 of the 37 dates the RapidEye water-land border (NIR) compared with the median of the distances to the according DEM contour line is negative, in the range of $-2 \mathrm{~m}$ to $-10 \mathrm{~m}$. At near-maximum lake level on 23 May 2012 the NIR water-land border is underestimated on average by $-4.1 \mathrm{~m}$, at the minimum lake level on 20 September 2009 by $-9.7 \mathrm{~m}$. Thirteen dates of the time series are characterized by (high) positive median distances up to several tens of meters. One of those outliers is 6 August 2014, the date of the field campaign with misclassifications due to cloud shadow. Data collected on 5 April 2012 is heavily disturbed by cloud shadow, data for 19 July 2010 only slightly. The six images between 12 October and 15 November are all characterized by a low sun elevation angle (SEA) $<30^{\circ}$. Due to the higher noise in those images, the automatic classification fails and the classification spreads into a dark clearing in the surrounding forest ( $c f$. Figure S6). The remaining images that overestimate the water surface area are dated 24 September 2011, 2 October 2011, 5 April 2012, 10 March 2014, 20 March 2014, 
and 24 September 2014. These dates have in common a SEA of $30^{\circ}$ and $45^{\circ}$ and a high lake level $\geq 63.7 \mathrm{~m}$ a.s.1. At this high lake level, the sandy beach is completely flooded. By contrast, images with a sandy beach (4 April 2009, 20 September 2009, 22 September 2010, and 4 October 2010) and a SEA between $30^{\circ}$ and $45^{\circ}$ underestimate the water surface area. A comparison of the contour lines with the extracted NIR water-land borders using the subset with $2.8 \%$ slope (ideal subset) can be found in Figure S7. Using the ideal subset the root mean squared error (RMSE) for all dates is $13.5 \mathrm{~m}$. After excluding the 12 images with low SEA, the RMSE sinks to $5.0 \mathrm{~m}$.

\subsection{Subset Selection for Lake Level Reconstruction}

A precise extraction of the water-land border is essential for an accurate reconstruction of the lake level. Another requirement for lake level reconstruction is the visibility of a water-land border change. Table 3 illustrates the shift of the water-land border at the minimum lake level to the water-land border at the maximum lake level in subsets with different slopes. The position of the subsets at the southeastern shoreline is shown in Figure 5. The subset with 8.7\% slope is located at the new public beach (cf. Figure 1). With shallower slope the distance between the minimum and maximum water-land border increases for the extracted water-land borders and for the contour lines from the DEM. The small shift of $5 \mathrm{~m}$ (=1 pixel) is too small for a reliable result, as intermediate lake extents cannot be delineated unambiguously. A shift of $10 \mathrm{~m}$ (=2 pixels) at least is theoretically required for the reconstruction of intermediate levels. At LF this means that only subsets with slopes $\leq 7.1 \%$ are suitable for lake level reconstruction.

Table 3. Average distances (in $\mathrm{m}$ ) between the water-land borders at the minimum lake level (20 September 2009, $63.15 \mathrm{~m}$ a.s.1.) and the maximum level of a cloud-free image (23 May 2012, $63.91 \mathrm{~m}$ a.s.1.) in subsets with various slopes (in percent).

\begin{tabular}{ccccc}
\hline $\begin{array}{c}\text { Slope } \\
(\%)\end{array}$ & $\begin{array}{c}\text { Distance between Minimum and } \\
\text { Maximum NIR Water-Land } \\
\text { Border (m) }\end{array}$ & $\begin{array}{c}\text { Distance between } \\
\text { Minimum and Maximum } \\
\text { Contour Lines (m) }\end{array}$ & $\begin{array}{c}\text { Location }(\boldsymbol{c f} \text {. } \\
\text { Figures 1 and 3) }\end{array}$ & Notes \\
\hline & & & & Trees flooded in \\
2.7 & 30.1 & 40.2 & Subset C & $\begin{array}{c}\text { August 2014, } \\
\text { high lake level }\end{array}$ \\
2.8 & 29.6 & 29.0 & Subset B & \\
3.7 & 29.1 & 21.6 & Subset B & \\
4.9 & 21.7 & 19.1 & Subset B & \\
5.1 & 22.2 & 16.3 & Subset B & \\
7.1 & 10.2 & 10.8 & Subset B & \\
8.7 & 5.3 & 8.9 & Subset A & \\
\hline
\end{tabular}

As this study aims at defining the most attainable accuracy, we conducted the reconstructed lake levels based on an "ideal" subset. The largest distances between the minimum and maximum water surface area are in the two shallowest subsets with $2.7 \%$ and $2.8 \%$ slopes ( $c f$. Table 3 ). However, only the subset with $2.8 \%$ slope is more or less free of vegetation. Thus, this subset was selected as the ideal subset. 


\subsection{Lake Level Reconstruction}

Although validation via DGPS showed more accurate results for the NDWI then for the NIR water-land border extraction, the time series analysis revealed an overestimation of the NDWI lake extent at low lake levels (Chapters 4.1 and 4.2). Thus, the following lake level reconstruction is based on the NIR water-land-borders and the ideal subset ( $c f$. Chapter 4.3).

Even in the case of the ideal subset, the intersection of the water-land border and the DEM results in a range of height values for every image/date. This is due to the different spatial resolutions of DEM and RapidEye images and small inaccuracies in the delineation of the water-land border. The range of height values per date is illustrated in Figure 7. A comparison of the mean, median and mode height values shows that the mode value is the most robust parameter. The mode value best represents the lake level, even in cases of misclassification of the water-land-border ( $c f$. dates 13 October 2011, 5 April 2012 and 10 March 2014). Thus, the mode value of the height values for one date is considered to be its lake level.

The reconstructed lake level is underestimated for 28 of 37 dates. The underestimate ranges from -20 to $-2 \mathrm{~cm}$, the average being $-11 \mathrm{~cm}$. For three dates the precise in situ lake level is reconstructed (19 July 2010, 2 October 2011, and 6 August 2014); however, two of those images are disturbed by cloud shadow (yellow highlighting in Figure 7). For six dates (17 October 2011, 22 October 2011, 13 November 2011, 12 October 2012, 14 November 2012, and 20 March 2014) the reconstructed lake levels are overestimated in the range of $6 \mathrm{~cm}$ to $79 \mathrm{~cm}$. The overestimations are caused by misclassifications in the extraction of the water-land border. As discussed before, the automatic detection of the water-land border has a reduced accuracy for images acquired at very low SEA $<30^{\circ}$ and for images with a SEA $<45^{\circ}$ in cases of high lake level ( $c f$. Table 2). In Figure 7 , all these images are highlighted in red. With removal of the 12 images, the RMSE between in situ measured and reconstructed levels is reduced from 22 to $12 \mathrm{~cm}$, and the absolute mean error from 14 to $11 \mathrm{~cm}$.

In a second step, we analyzed the relative level changes $\Delta h=h(t)-h(t+1)$ of dates without misclassifications in the ideal subset in Figure 8. For the monitoring period, the absolute mean of difference of $\Delta h$ (in situ) and $\Delta h$ (reconstructed) is $5 \mathrm{~cm}$, the RMSE $6 \mathrm{~cm}$. In 2009 and 2010, the lake level is so low that there is a wide sandy area between the lake and surrounding vegetation. At those times, the in situ measured and the reconstructed lake level changes are very similar: the difference between $\Delta h$ (in situ) and $\Delta h$ (reconstructed) ranges only about $\pm 5 \mathrm{~cm}$ (absolute average $=3 \mathrm{~cm}$, RMSE $=3 \mathrm{~cm}$ ). The only larger deviations on 19 July 2010 and 22 September 2010 can be explained by cloud shadows on image 19 July 2010 and the resulting overestimation of the water level. In 2011 the lake level increases significantly and the sandy beach is flooded. Also, in 2011 the deviations between $\Delta h$ (in situ) and $\Delta h$ (reconstructed) grow larger (absolute average $5 \mathrm{~cm}, \mathrm{RMSE}=6 \mathrm{~cm}$ ), with a maximum delta of $-13 \mathrm{~cm}$. However still, the reconstructed level changes are close to the trends of the changes determined by in situ measurement. Since 2012, the year with the highest lake level, the accordance of reconstructed and in situ measured level changes decreases significantly. The difference of $\Delta h$ (in situ) and $\Delta h$ (reconstructed) ranges from $-7 \mathrm{~cm}$ to $+19 \mathrm{~cm}$ (absolute average $6 \mathrm{~cm}$, RMSE $=8 \mathrm{~cm}$ ). Several times the reconstructed and the in situ measured lake levels show opposite lake level changes. The most conspicuous outlier (6 August 2014) is caused by cloud shadow. 


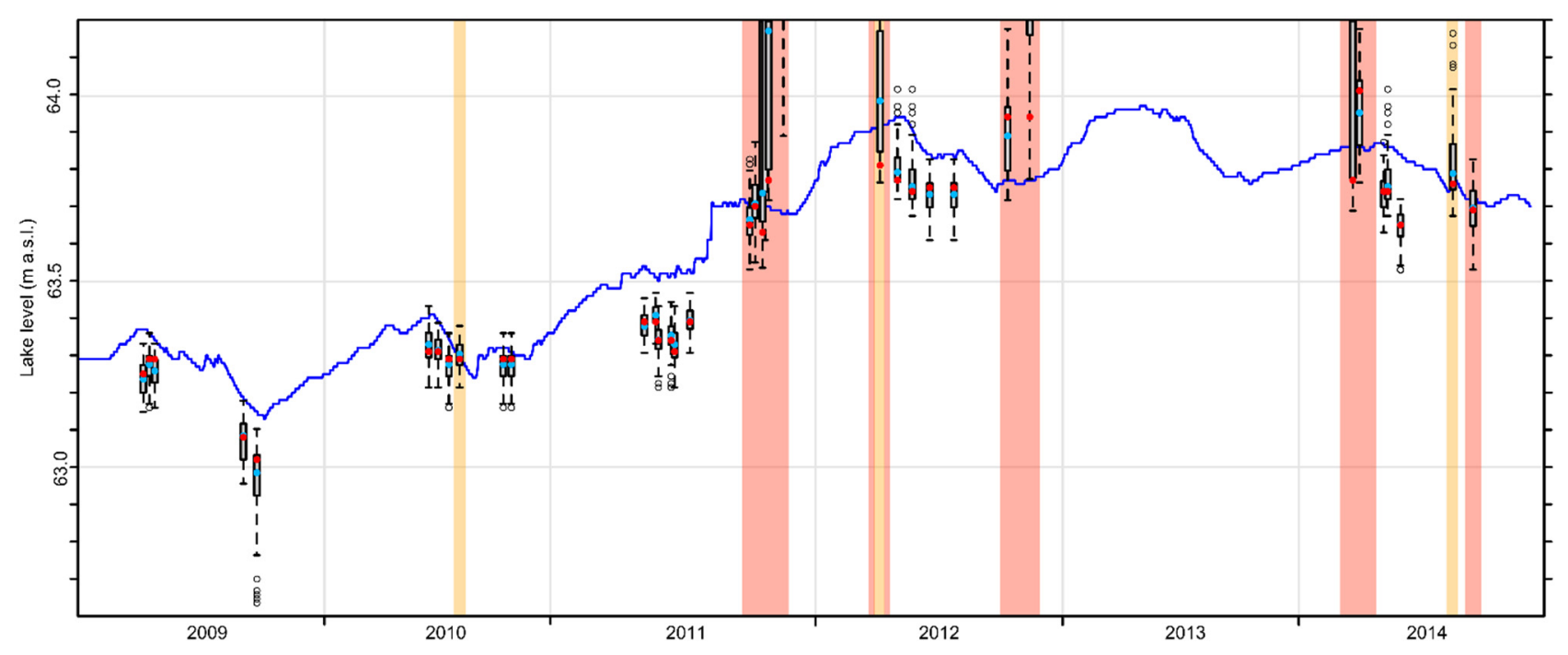

Figure 7. Illustration of the in situ measured and reconstructed lake levels at LF. The boxplots show the range of height values based on the intersection of the water-land border in the ideal subset with $2.8 \%$ slope with the high-resolution DEM. The mode value of a boxplot is considered to be the lake level at the according date. The blue line shows the in situ measured lake level ranges between January 2009 and November 2014. The red dots are the mode value, the light blue dots the median value for each date. Red highlighted are all dates with a very low sun elevation angle (SEA) below $<30^{\circ}$ and dates with a SEA angle below $<45^{\circ}$ in cases of high lake levels ( $\geq 63.7 \mathrm{~m}$ a.s.1.). Yellow highlighted $\mathrm{RE}$ images are disturbed by significant cloud shadows.

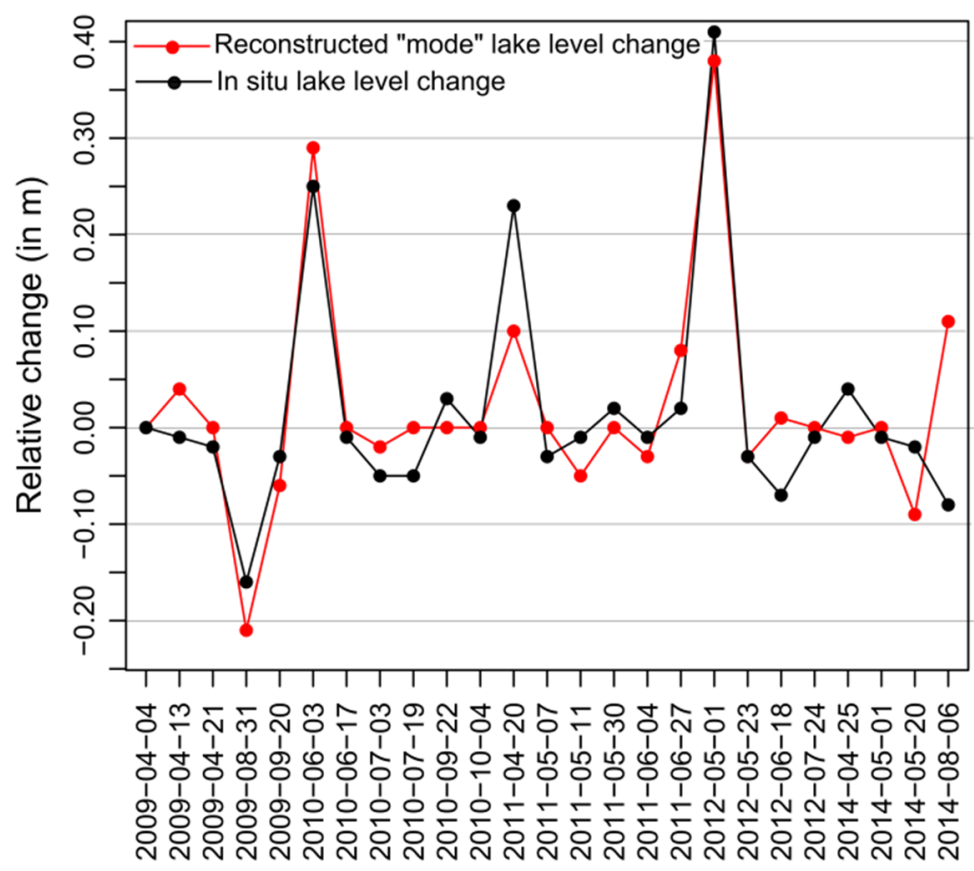

Figure 8. The black line shows the relative changes $\Delta h$ (in situ) of the in situ measured level, the red line the relative changes $\Delta h$ (reconstructed) of the reconstructed "mode" levels. Twelve dates were removed because of low sun elevation angles. 
Finally, we compare the relative changes of the ideal subset with the results of the five other subsets with various slopes ( $c f$. Figure 5). The results are depicted in Figure 9.

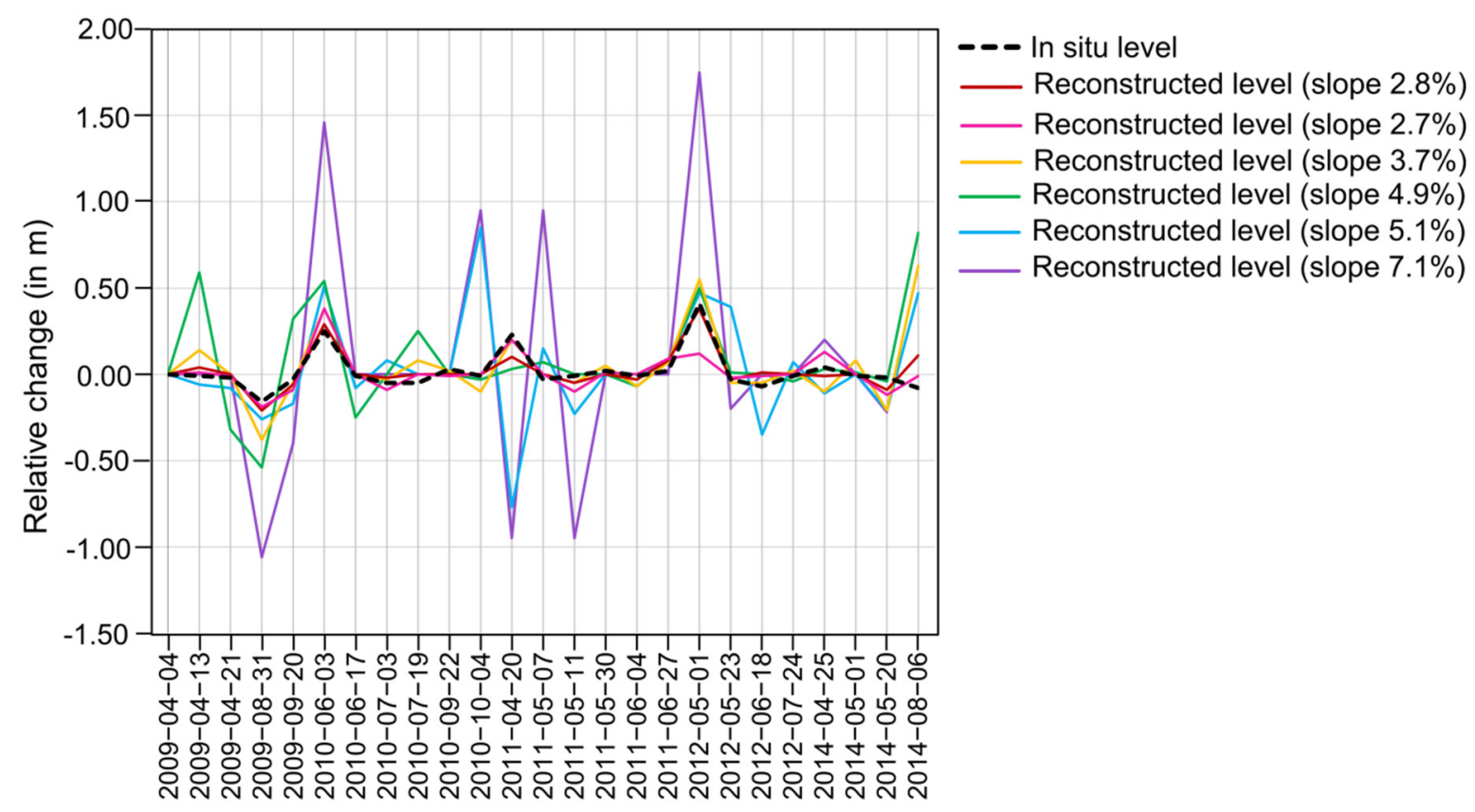

Figure 9. Relative changes $(\Delta h=h(t)-h(t+1))$ of the reconstructed lake levels ("mode values"). The black dashed line is the relative change of the level measured in situ. The colored lines represent the relative changes of the reconstructed lake levels.

As expected, the shallower the slopes, the higher the precision in the reconstruction of the lake level changes: the level changes using the two shallowest subsets are very similar until the end of 2011. After 2011, the shallowest subset (2.7\% slope) shows larger deviations and partly contrary changes. As stated above, the inaccuracies in the shallowest subset are most likely caused by vegetation that covers the water surface. The subset with $3.7 \%$ slope still shows the same ups and downs as the lake level change measured in situ, but generally has larger deviations and outliers in 2014. The three steepest subsets (slopes of $4.9 \%, 5.1 \%$ and $7.1 \%$ ) are all characterized by large deviations and outliers, most eye-catching at 20 April 2011.

\section{Discussion}

This study suggests that high-resolution RapidEye archive data are a valuable source for reconstructing former lake levels. It also demonstrates the importance of the shoreline slope, vegetation, and shadows (and thus solar angle) for accurately reconstructing the lake level.

Under ideal conditions, the lake levels can be measured indirectly with the NIR water-land borders in decimeter resolution. This is a significant improvement compared to previous lake level retrievals based on medium resolution data with only one-meter precision [16]. Annual and seasonal fluctuations as well as short-term (within two weeks) jumps in lake level were detected. However, for a very high-resolution temporal monitoring of daily changes or changes within one week, the changes in lake level were too small. The maximum level changes within one week are only in the range of $\pm 5 \mathrm{~cm}$, with small changes in the water-land border. The decimeter accuracy (RMSE $12 \mathrm{~cm}$, absolute mean 
error $11 \mathrm{~cm}$ ) of the indirect lake level reconstruction is in line with the accuracy of flood level estimations based on high-resolution data $[53,54]$ and even better than a previous study in northeastern Germany using aerial photos [33]. However, the levels were systematically underestimated in the range of $-20-0 \mathrm{~cm}$ (excluding images with sever misclassification of the water-land border). The underestimation of the lake levels is caused by the underestimation of the water extent in the automatic extraction of the water-land border. Due to this systematic underestimation of absolute lake levels, an analysis of relative changes is preferred. The accuracy of the relative changes is generally high $($ RMSE $=6 \mathrm{~cm})$, but difference between times with sandy beaches and times with flooded beaches became visible: whereas the accuracy in 2009 and 2010 with a sandy beach was very high with $($ RMSE $=3 \mathrm{~cm})$, it declined massively to approx. $\pm 20 \mathrm{~cm}($ RMSE $6 \mathrm{~cm})$ with higher lake levels and a flawless transition of water to vegetation. This shows that the accuracy of the lake level retrieval depends on terrain and vegetation cover on the lake shore. Thus, the accuracy of the lake level retrieval can change over the monitoring period due to changing shoreline conditions at different dates and lake levels.

Essential for an accurate lake level reconstruction is the precise delineation of the water-land border and precise topographic data. Other studies just compare their extracted coastline at different times without absolute validation of the shoreline precision [21,22]. We validated the delineated water-land borders with DGPS measurements and with contour lines from the DEM. The water-land borders were extracted from the RE images automatically using Otsu's threshold on the NIR bands and the NDWI images. Whereas the NDWI water-land border had a higher accuracy in the DGPS validation, the time series revealed significate overestimations of the water extent, which fits to the findings of Li et al., 2013 [49]. The extraction of the water-land borders via NIR showed a higher sensitivity to (cloud) shadows, but was also more precise in the delineation of water at low water levels. Thus, we decided to use NIR for the lake level reconstruction.

The sensitivity of NIR and NDWI to shadows is a well-known problem and causes misclassifications [14,16,47,55-57]. Shadows of trees and buildings caused small misclassifications that were easily filtered by only taking the longest line as the water-land border. Analysis of the NIR water-land borders and the reconstructed lake levels showed that cloud shadows, such as in the RapidEye image contemporary to the field campaign with the DGPS measurements, could lead to an overestimation of water extent and thus to a relatively higher reconstructed lake level (smaller or no underestimation). This finding confirms the importance of validation with contour lines.

The accuracy of the NIR water-land borders (without misclassified images due to low solar angles) in comparison to the according contour lines at the ideal subset with $2.8 \%$ slope is RMSE $=5.0 \mathrm{~m}$; for the subset $\mathrm{B}$ the RMSE $=10.8 \mathrm{~m}$. A deviation between the NIR water-land border and the contour line is expected due to the different spatial resolutions of the RapidEye images and the DEM. In a previous study with a very high resolution IKONOS image, the RMSE between the delineation of sandy coastlines and the in situ measured water-land border was approx. $6 \mathrm{~m}$ [20]. Another study with medium-resolution Landsat data estimates its accuracy as 1.3 pixels (pixel size $=30 \mathrm{~m}$ ) [18]. Systematic underestimation of the NIR water-land border is caused by the inherent sensitivity of NIR reflectance in littoral zones with very shallow water columns and by the spectral mixture of water and land $[17,58]$. Underestimation of the water-land border via NIR band is confirmed by Wang et al., 2014 [17]. However, it needs to be considered that the contour lines in the GIS analysis in this study probably differ from the in situ determined water-land borders due to inaccuracies in the DEM, 
specifically in the area of the underwater surface model and because of the different resolutions of the RapidEye image and the DEM.

Essential for the unambiguous reconstruction of different levels is also a clear shift of the water-land border with increasing lake level. This shift needs to be several times larger than the pixel size. This study finds that for RapidEye images a $30 \mathrm{~m}$ (=6 pixels) shift between minimum and maximum levels (80 cm level difference) is necessary for reconstructing lake levels with decimeter accuracy. A $30 \mathrm{~m}$ shift is reached at shoreline slopes $<4 \%$. A smaller shift significantly reduced the accuracy of lake level reconstruction, so only a trend in lake level changes could be estimated. The ideal subset for lake level reconstruction at LF has a $2.8 \%$ slope.

In summary, the requirements for lake level reconstruction with decimeter accuracy are:

1. The water-land border needs to be delineated precisely. The automatic Otsu threshold on the NIR band showed the best results, but the approach is sensitive to shadows and thus to low solar angles. Dense vegetation cover hinders the accurate retrieval of water-land borders.

2. The topographic data needs to be accurate as the lake level reconstruction is only as good as the underlying DEM. This is specifically true for the underwater surface model, which is not of very high quality due to sparse bathymetric point measurements. Due to the different quality levels of the DEM, the accuracy of lake level reconstruction depends here also on the lake level itself.

3. The shoreline subset that is used for the retrieval of the lake level needs to be very shallow, so that the shift of the water-land border with changing lake level is maximized. Using RapidEye images, a decimeter accuracy of lake level reconstruction is only feasible if the shoreline slope is less than $3 \%$.

These requirements are very strict and only very few lakes can fulfill the demands. Suitable lakes with shallow shorelines are, for example, Lake Wittwesee near Reihnsberg, Lake Redernswalder See near Parlow-Glambeck, Lake Briesensee near Poritz, and Lake Stechlin near Neuglobsow. The above-mentioned suitable lake sites are characterized by having little or no vegetation on sandy beaches during low level periods in the time range of the RapidEye acquisitions. However, at high lake levels reed vegetation often colonizes the shallow shorelines.

Another limitation on regular lake level monitoring is the actual temporal resolution of the RapidEye time series, with often less than one image per month and no suitable images from September/October until April. Frequent clouds coverage as well as cloud shadows reduced the temporal resolution of the RapidEye time series massively. Additionally, low solar angles during wintertime result in larger shadows and a worse signal-to-noise-ratio so that land is mistaken for water in the automatic classification. As a consequence, images with a very low SEA $<30^{\circ}$ and images with a low SEA between $30^{\circ}$ and $45^{\circ}$ during high lake levels needed to be removed. Thus, at LS only $75 \%$ of the RapidEye images in the archive could be finally used for the lake level reconstruction.

Nevertheless, monitoring lake level changes remains a hot topic as only ca. 500 of the $c a .5000$ lakes in northeastern Germany have regular gauging stations [59,60] and because the RapidEye time series analysis in this study clearly showed the significance of lake level and shoreline changes for ecologic and economic reasons: Within one season, between April 2009 and September 2009, the size of the sandbank decreased by $90 \%$ and within one year the sandbank and shallow sandy beaches were completely 
flooded. This rapid change has high ecological impact on LF. For tourism the vanishing old public beach (subset B) with its wide sandy beach was a loss of attraction and at the new public beach (subset A) a swimming pier needed to be relocated. Also important was the flooding of the land connection of the peninsula in the southwest and the drowning of trees (subset C). The increase in lake level also influenced the submerged and aquatic vegetation: whereas the drying out of the shallow areas at low lake levels led to a significant reduction in the amount of pondweed and stonewort [1]; the shallow water areas were again colonized with reed in 2014. It is hoped that with a continuous high lake level the former underwater macrophytes will recolonize to stabilized and secure clear water conditions.

\section{Conclusions}

In this study, we measured lake levels indirectly by combining information on the water-land borders derived from high-resolution multi-spectral satellite images (RapidEye) and high-resolution topographic data. The results showed that the reconstruction of lake level changes worked well even for small and short-term lake levels changes. The RMSE between in situ measured lake level changes and reconstructed lake level changes was $6 \mathrm{~cm}$. The absolute lake levels were reconstructed with decimeter accuracy, but they showed a systematic underestimation by $-20-0 \mathrm{~cm}$. The RMSE between in situ measured lake levels and reconstructed lake levels was $12 \mathrm{~cm}$.

We tested two approaches for retrieval of water-land borders: automatic thresholds (Otsu) of the NIR bands and of the NDWI images. This study showed that NIR water-land borders were more precise than NDWI water-land borders, but also more sensitive to shadows. The RMSE between NIR water-land borders and according contour lines was $5.0 \mathrm{~m}$ (excluding winter images). Limitations in the accuracy of the delineation of the water-land border are caused by the characteristics of the RapidEye sensors and by the interfering shoreline vegetation. Mixed water and land pixels lead to an underestimation of the NIR water-land border. Due to changing shoreline conditions at different dates and lake levels, the accuracy of the lake level delineation can change over the monitoring period. The sensitivity of the NIR band to shadows causes severe misclassifications in the NIR water-land borders, especially in winter with low SEA angles. Clouds and shadows reduce significantly the repeat interval of usable RapidEye data acquisitions. Possible alternatives to tackle the limitations of the RapidEye optical system could be very high resolution data or Synthetic Aperture Radar (SAR). However, both alternatives bring new challenges. The use of very high resolution data (e.g., Worldview-2, Quickbird, Spot) for higher precision of water-land border determination comes with high cost of the images. SAR sensors are sunlight independent and able to penetrate clouds and light rain [61]. However, the side-looking geometry of the sensors is a disadvantage for spatially precise monitoring of shorelines [5].

The time series analysis of the NIR water-land borders at LF showed significant shifts of the shoreline with increasing lake levels. This is essential for the unambiguous reconstruction of different lake levels. The shift needs to be several times larger than the pixel size. For RapidEye images, at least a $30 \mathrm{~m}$ (6 pixels) shift between minimum and maximum lake levels ( $80 \mathrm{~cm}$ level difference) is necessary for reconstructing lake levels with decimeter accuracy. Such a $30 \mathrm{~m}$ shift results from shoreline slopes $<4 \%$. A smaller shift significantly reduces the accuracy of lake level reconstruction, so only a trend in lake level changes could be estimated. 
Our results show that the reconstruction of small lake level changes can only be achieved using high resolution topographic data. For better accuracy, LIDAR acquisitions at low lake levels could substitute medium-resolution bathymetric surveys in shallow parts of the lake. As long as erosion and sedimentation rates are low, one-time acquisition of additional topographic data would be sufficient.

For the natural lakes in northeastern Germany and Poland, the transferability of the approach is limited, because of the specific requirements of the method. The very shallow shoreline slopes of the natural lakes often exhibit dense shoreline vegetation. Our experience indicates that the approach can be transferred to lakes with shorelines affected by human activity which keeps the shores free of vegetation such as public beaches or watering places. Additionally, the use of the lakes as reservoirs and fish ponds often introduces significant lake level changes.

\section{Supplementary Materials}

Supplementary materials can be found at: http://www.mdpi.com/2073-4441/7/8/4175/s1.

\section{Acknowledgments}

We would like to thank Julian Oeser and Robert Behling for their help in processing the RapidEye images and Christian Hohmann for his help in the field campaign. We are also grateful to our anonymous reviewers for their helpful and constructive comments.

This study was funded by the "Helmholtz Association of German Research Centres Initiative-Networking Fund for funding a Helmholtz Virtual Institute" (VH-VI-415). Satellite imagery was provided by ESA (proposal no. 14611) and BlackBridge (RESA Projekt-ID A1274).

\section{Author Contributions}

Iris Heine developed the methodological framework, performed programming, and conducted the analysis. Birgit Kleinschmit and Sibylle Itzerott were involved in formulating the research questions, preparing the manuscript, and contributing to critical discussions. Iris Heine, Birgit Kleinschmit and Sibylle Itzerott were involved in the general paper review. Peter Stüve supported the study by providing in situ data as well as expert knowledge about the gauging and the study area.

\section{Conflicts of Interest}

The authors declare no conflict of interest.

\section{References}

1. Kaiser, K.; Friedrich, J.; Oldorff, S.; Germer, S.; Mauersberger, R.; Natkhin, M.; Hupfer, M.; Pingel, A.; Schönfelder, J.; Spicher, V.; et al. Aktuelle hydrologische Veränderungen von Seen in Nordostdeutschland: Wasserspiegeltrends, ökologische Konsequenzen, Handlungsmöglichkeiten. In Wasserbezogene Anpassungsmaßnahmen an den Landschafts- und Klimawandel; Grünewald, U., Bens, O., Fischer, H., Hüttl, R.F., Kaiser, K., Eds.; Schweizerbart Science Publishers: Stuttgart, Germany, 2012; pp. 148-170. 
2. Mauersberger, R. Klassifikation der Seen für die Naturraumerkundung des nordostdeutschen Tieflandes. Arch. Naturschutz Landschaftsforsch. 2006, 3, 51-90.

3. Germer, S.; Kaiser, K.; Bens, O.; Hüttl, R.F. Water Balance Changes and Responses of Ecosystems and Society in the Berlin-Brandenburg Region-A Review. DIE ERDE J. Geogr. Soc. Berlin 2011, 142, 65-95.

4. Kaiser, K.; Koch, P.J.; Mauersberger, R.; Stüve, P.; Dreibrodt, J.; Bens, O. Detection and attribution of lake-level dynamics in north-eastern central Europe in recent decades. Reg. Environ. Chang. 2014, 14, 1587-1600.

5. Heine, I.; Francke, T.; Rogass, C.; Medeiros, P.H.A.; Bronstert, A.; Foerster, S. Monitoring Seasonal Changes in the Water Surface Areas of Reservoirs Using TerraSAR-X Time Series Data in Semiarid Northeastern Brazil. J. Sel. Top. Appl. Earth Obs. Remote Sens. 2014, 7, 3190-3199.

6. Van de Weyer, K.; Päzolt, J.; Tigges, P.; Raape, C.; Oldorff, S. Flächenbilanzierungen submerser Pflanzenbestände-Dargestellt am Beispiel des Großen Stechlinsees (Brandenburg) im Zeitraum von 1962-2008. Naturschutz Landschaftspfl. Brand. 2009, 18, 1-6.

7. Brauns, M.; Garcia, X.F.; Pusch, M.T. Potential effects of water-level fluctuations on littoral invertebrates in lowland lakes. Hydrobiologia 2008, 613, 5-12.

8. Landesamt Brandenburg. Ökologische Charakterisierung der wichtigsten Brutgebiete für Wasservögel in Brandenburg. Stud. Tagungsberichte 2008, 57, 1-181.

9. Landesumweltamt Brandenburg (Ed). Leitfaden zur Renaturierung von Feuchtgebieten in Brandenburg. Studien und Tagungsberichte des Landesumweltamtes, 2004; No. 50. Available online: http://www.lugv.brandenburg.de/cms/media.php/lbm1.a.3310.de/lua_bd50.pdf (accessed on 29 July 2015).

10. Schmieder, K.; Dienst, M.; Ostendorp, W.; Joehnk, K. Effects of water level variations on the dynamics of the reed belts of Lake Constance. Ecohydrol. Hydrobiol. 2004, 4, 469-480.

11. Hilt, S.; Henschke, I.; Rücker, J.; Nixdorf, B. Can submerged macrophytes influence turbidity and trophic state in deep lakes? Suggestions from a case study. J. Environ. Qual. 2010, 39, 725-733.

12. Hupfer, M.; Nixdorf, B. Zustand und Entwicklung von Seen in Berlin und Brandenburg. Materialien der Interdisziplinären Arbeitsgruppen (IAG Globaler Wandel-Regionale Entwicklung); Berlin-Brandenburgische Akademie der Wissenschaften: Leipzig, Germany, 2011; Diskussionspapier, No. 11.

13. Ulrich, K.U. Vergleichende Untersuchungen zur Auswirkungen des Sediments auf die Wasserbeschaffenheit in Trinkwassertalsperren unter Berücksichtigung von Stauspiegelschwankungen; Cuvillier Verlag: Göttingen, Germany, 1998.

14. Verpoorter, C.; Kutser, T.; Tranvik, L. Automated mapping of water bodies using Landsat multispectral data. Limnol. Oceanogr. Methods 2012, 10, 1037-1050.

15. Muster, S.; Heim, B.; Abnizova, A.; Boike, J. Water Body Distributions Across Scales: A Remote Sensing Based Comparison of Three Arctic TundraWetlands. Remote Sens. 2013, 5, 1498-1523.

16. Maillard, P.; Pivari, M.O.; Luis, C.H.P. Remote Sensing for Mapping and Monitoring Wetlands and Small Lakes in Southeast Brazil. In Remote Sensing of Planet Earth; Chemin, Y., Ed.; InTech: Rijeka, Croatia, 2012; pp. 23-46.

17. Wang, J.; Sheng, Y.; Tong, T.S.D. Monitoring decadal lake dynamics across the Yangtze Basin downstream of Three Gorges Dam. Remote Sens. Environ. 2014, 152, 251-269. 
18. Alesheikh, A.; Ghorbanali, A.; Nouri, N. Coastline change detection using remote sensing. Int. J. Environ. Sci. Technol. 2007, 4, 61-66.

19. White, K.; El Asmar, H.M. Monitoring changing position of coastlines using Thematic Mapper imagery, an example from the Nile Delta. Geomorphology 1999, 29, 93-105.

20. Lipakis, M.; Chrysoulakis, N. Shoreline extraction using satellite imagery. In Beach Erosion Monitoring: Results from BEACHMED-e/OpTIMAL Project; Pranzini, E., Wetzel, L., Eds.; Nuova Grafica Fiorentina: Florence, Italy, 2008; pp. 81-96.

21. Li, X.; Damen, M.C.J. Coastline change detection with satellite remote sensing for environmental management of the Pearl River Estuary, China. J. Mar. Syst. 2010, 82, S54-S61.

22. Gens, R. Remote sensing of coastlines: Detection, extraction and monitoring. Int. J. Remote Sens. 2010, 31, 1819-1836.

23. Pardo-Pascual, J.E.; Almonacid-Caballer, J.; Ruiz, L.A.; Palomar-Vázquez, J. Automatic extraction of shorelines from Landsat TM and ETM+ multi-temporal images with subpixel precision. Remote Sens. Environ. 2012, 123, 1-11.

24. Baup, F.; Frappart, F.; Maubant, J. Combining high-resolution satellite images and altimetry to estimate the volume of small lakes. Hydrol. Earth Syst. Sci. 2014, 18, 2007-2020.

25. Maillard, P.; Bercher, N.; Calmant, S. New processing approaches on the retrieval of water levels in Envisat and SARAL radar altimetry over rivers: A case study of the São Francisco River, Brazil. Remote Sens. Environ. 2015, 156, 226-241.

26. Abarca-Del-Rio, R.; CrÉtaux, J.F.; Berge-Nguyen, M.; Maisongrande, P. Does Lake Titicaca still control the Lake Poopó system water levels? An investigation using satellite altimetry and MODIS data (2000-2009). Remote Sens. Lett. 2012, 3, 707-714.

27. Da Silva, J.S.; Seyler, F.; Calmant, S.; Rotunno Filho, O.C.; Roux, E.; Araújo, A.A.M.; Guyot, J.L. Water level dynamics of Amazon wetlands at the watershed scale by satellite altimetry. Int. J. Remote Sens. 2012, 33, 3323-3353.

28. Gupta, R.; Banerji, S. Monitoring of reservoir volume using LANDSAT data. J. Hydrol. 1985, 77, 159-170.

29. Smith, L.C. Satellite remote sensing of river inundation area, stage, and discharge: A review. Hydrol. Process. 1997, 11, 1427-1439.

30. Brakenridge, G.R.; Nghiem, S.V.; Anderson, E.; Chien, S. Space-based measurement of river runoff. Eos Trans. Am. Geophys. Union 2005, 86, 185.

31. Alsdorf, D.E.; Rodriguez, E.; Lettenmaier, D.P. Measuring surface water from space. Rev. Geophys. 2007, 45, 1-24.

32. Hostache, R.; Matgen, P.; Schumann, G.; Member, S.; Puech, C.; Hoffmann, L.; Pfister, L. Model Calibration Uncertainties Using Satellite SAR Images of Floods. Trans. Geosci. Remote Sens. 2009, 47, 431-441.

33. Kaiser, K.; Heinrich, I.; Heine, I.; Natkhin, M.; Dannowski, R.; Lischeid, G.; Schneider, T.; Henkel, J.; Küster, M.; Heussner, K.; et al. Multi-decadal lake-level dynamics in north-eastern Germany as derived by a combination of gauging, proxy-data and modelling. J. Hydrol. 2015, in press. 
34. Germer, S.; Kaiser, K.; Mauersberger, R. Sinkende Seespiegel in Nordostdeutschland: Vielzahl hydrologischer Spezialfälle oder Gruppen von Ähnlichen Seesystemen? In Aktuelle Probleme im Wasserhaushalt von Nordostdeutschland: Trends, Ursachen, Lösungen; Scientific Technical Report 10/10; Deutsches GeoForschungsZentrum: Potsdam, Germany, 2010.

35. Data from Deutscher Wetterdienst. Available online: http://www.dwd.de/ (accessed on 10 March 2015).

36. Landesamt für Umwelt Naturschutz und Geologie Mecklenburg-Vorpommern. Gutachtlicher Landschaftsrahmenplan Mecklenburgische Seenplatte, 2011. Available online: http://www.lung. mv-regierung.de/dateien/glrp_ms_06_2011.pdf (accessed on 29 July 2015).

37. Ministerium für Landwirtschaft, Umwelt und Verbraucherschutz Mecklenburg-Vorpommern. Available online: http://www.regierung-mv.de/cms2/Regierungsportal_prod/Regierungsportal/ $\mathrm{de} / \mathrm{lm} /$ index.jsp (accessed on 4 December 2014).

38. Staatliches Amt für Landwirtschaft und Umwelt Mecklenburgische Seenplatte (MS). Available online: http://www.stalu-mv.de/cms2/StALU_prod/StALU/de/ms/index.jsp (accessed on 8 January 2015).

39. Sandau, R. Status and trends of small satellite missions for Earth observation. Acta Astronaut. 2010, 66, 1-12.

40. Landesamt für innere Verwaltung Mecklenburg Vorpommern. Available online: http://www.laiv-mv.de/land-mv/LAiV_prod/LAiV/AfGVK/index.jsp (accessed on 3 May 2013).

41. RapidEye - Satellite Imagery Product Specifications, Version 6.1, April 2015. Available online: http://blackbridge.com/rapideye/upload/RE_Product_Specifications_ENG.pdf (accessed on 27 July 2015).

42. Behling, R.; Roessner, S.; Segl, K.; Kleinschmit, B.; Kaufmann, H. Robust automated image co-registration of optical multi-sensor time series data: Database generation for multi-temporal landslide detection. Remote Sens. 2014, 6, 2572-2600.

43. Amt für Geoinformation, V.K. Satellitenpositionierungsdienst-SAPOS ${ }^{\circledR}$. Available online: http://www.laiv-mv.de/land-mv/LAiV_prod/LAiV/AfGVK/Festpunkte,_SAPOS/SAPOS/index.jsp (accessed on 27 July 2015).

44. Arbor, A.; Gilmer, D.S.; Fish, U.S.; Service, W. Utilization of Satellite Data for Inventorying Prairie Ponds and Lakes. Photogramm. Eng. Remote Sens. 1976, 42, 685-694.

45. Kropáček, J.; Braun, A.; Kang, S.; Feng, C.; Ye, Q.; Hochschild, V. Analysis of lake level changes in Nam Co in central Tibet utilizing synergistic satellite altimetry and optical imagery. Int. J. Appl. Earth Obs. Geoinf. 2012, 17, 3-11.

46. Roessler, S.; Wolf, P.; Schneider, T. Multispectral Remote Sensing of Invasive Aquatic Plants Using RapidEye. In Earth Observation of Global Changes (EOGC); Krisp, J.M., Meng, L., Pail, R., Stilla, U., Eds.; Lecture Notes in Geoinformation and Cartography; Springer: Berlin, Germany, 2013; pp. 109-123.

47. Ji, L.; Zhang, L.; Wylie, B. Analysis of Dynamic Thresholds for the Normalized Difference Water Index. Photogramm. Eng. Remote Sens. 2009, 75, 1307-1317.

48. Lu, S.; Ouyang, N.; Wu, B.; Wei, Y.; Tesemma, Z. Lake water volume calculation with time series remote-sensing images. Int. J. Remote Sens. 2013, 34, 7962-7973. 
49. Li, W.; Du, Z.; Ling, F.; Zhou, D.; Wang, H.; Gui, Y.; Sun, B.; Zhang, X. A Comparison of Land Surface Water Mapping Using the Normalized Difference Water Index from TM, ETM+ and ALI. Remote Sens. 2013, 5, 5530-5549.

50. McFeeters, S.K. The use of the Normalized Difference Water Index (NDWI) in the delineation of open water features. Int. J. Remote Sens. 1996, 17, 1425-1432.

51. Lu, S.; Wu, B.; Yan, N.; Wang, H. Water body mapping method with HJ-1A/B satellite imagery. Int. J. Appl. Earth Obs. Geoinf. 2011, 13, 428-434.

52. Otsu, N. A threshold selection method from Gray-level. IEEE Trans. Syst. Man Cybern. 1979, 9 , 62-66.

53. Puech, C.; Raclot, D. Using geographical information systems and aerial photographs to determine water levels during floods. Hydrol. Process. 2002, 16, 1593-1602.

54. Hostache, R.; Matgen, P.; Schumann, G.; Puech, C.; Hoffmann, L.; Pfiste, L. Water level estimation and reduction of hydraulic model calibration uncertainties using satellite SAR images of floods. Trans. Geosci. Remote Sens. 2009, 47, 431-441.

55. Bochow, M.; Heim, B.; Küster, T.; Rogaß, C.; Bartsch, I.; Segl, K.; Reigber, S.; Kaufmann, H. On the Use of Airborne Imaging Spectroscopy Data for the Automatic Detection and Delineation of Surface Water Bodies. In Remote Sensing of Planet Earth; Chemin, Y., Ed.; InTech: Rijeka, Croatia, 2012; pp. 3-22.

56. Lira, J. Segmentation and morphology of open water bodies from multispectral images. Int. J. Remote Sens. 2006, 27, 4015-4038.

57. Qiao, C.; Luo, J.; Sheng, Y.; Shen, Z.; Zhu, Z.; Ming, D. An Adaptive Water Extraction Method from Remote Sensing Image Based on NDWI. J. Indian Soc. Remote Sens. 2012, 40, 421-433.

58. Davaasuren, N.; Meesters, H.W.G. Extent and Health of Mangroves Mangroves in Lac Bay Bonaire Using Satellite Data; IMARES Wageningen UR: Haringkade, The Netherland, 2012.

59. Päzolt, J. Landesamt für Umwelt, Gesundheit und Verbraucherschutz, Brandenburg, Germany. Personal Communication, 2015.

60. Mathes, J. Ministerium für Landwirtschaft, Umwelt und Geologie, Mecklenburg-Vorpommers, Germany. Personal Communication, 2015.

61. Lillesand, T.M.; Kiefer, R.W.; Chipman, J.W. Remote Sensing and Image Interpretation, 6th ed.; Wiley: Hoboken, NJ, USA, 2008.

(C) 2015 by the authors; licensee MDPI, Basel, Switzerland. This article is an open access article distributed under the terms and conditions of the Creative Commons Attribution license (http://creativecommons.org/licenses/by/4.0/). 